\title{
UPAYA MENINGKATKAN HASIL BELAJAR PENDIDIKAN AGAMA ISLAM MELALUI PENERAPAN METODE PEMBELAJARAN DEMONSTRASI DI KELAS VII-1 SMP NEGERI 2 BINJAI KAB. LANGKAT
}

\author{
Halimatussa'diah \\ Surel: halimatussakdiahlangkat@gmail.com
}

\begin{abstract}
The purpose of this study was to determine the increase in Islamic education learning outcomes on the subject of plural prayer and Qashar through the application of demonstration learning methods in class VII-1 of Binjai District 2 Middle School. Langkat. This research design is a Class Action Research using the Kemmis and Taggart research model, which is spiral from one cycle to the next. The results of this study are: 1) In Cycle I the implementation of the learning model Demonstrations obtained student learning outcomes from 26 students obtained 19 people who completed $73.1 \%$ and 7 people who did not complete with $26.9 \%$. 2) In the second cycle student learning outcomes from 26 students were obtained 23 people who completed $88.5 \%$ and 3 people who did not complete with $11.5 \%$. From the findings of this study it can be concluded that the application of demonstration learning methods can improve the learning outcomes and skills of plural prayers and qasar of class VII-1 students of SMP Negeri 2 Binjai, Kab. Langkat.
\end{abstract}

Keywords: Learning Model, Demonstration, PAI

\begin{abstract}
ABSTRAK
Tujuan penelitian ini adalah untuk mengetahui peningkatan hasil belajar pendidikan Agama Islam pada pokok bahasan sholat Jamak dan Qashar melalui penerapan metode pembelajaran demonstrasi di kelas VII-1 SMP Negeri 2 Binjai Kab. Langkat. Desain Penelitian ini adalah Penelitian Tindakan Kelas menggunakan model penelitian kemmis dan taggart, yaitu berbentuk spiral dari siklus yang satu ke siklus yang berikutnya. Adapun hasil penelitian ini adalah: 1) Pada Siklus I penerapan model pembelajaran Demonstrasi memperoleh hasil belajar siswa dari 26 orang siswa diperoleh 19 orang yang tuntas dengan $73,1 \%$ dan 7 orang yang tidak tuntas dengan 26,9\%. 2) Pada siklus II hasil belajar siswa dari 26 orang siswa diperoleh 23 orang yang tuntas dengan $88,5 \%$ dan 3 orang yang tidak tuntas dengan $11,5 \%$. Dari temuan penelitian ini dapat ditarik kesimpulan penerapan metode pembelajaran demonstrasi dapat meningkatkan hasil belajar dan keterampilan sholat jamak dan qasar siswa kelas VII-1 SMP Negeri 2 Binjai Kab. Langkat.
\end{abstract}

Kata Kunci: Model Pembelajaran, Demonstrasi, PAI

\section{PENDAHULUAN}

Agama memiliki peran yang amat penting dalam kehidupan umat manusia.Agama menjadi pemandu dalam upaya mewujudkan suatu kehidupan yang bermakna, damai dan bermartabat. Menyadari bahwa betapa pentingnya peran agama bagi kehidupan umat manusia maka internalisasi nilai-nilai agama 
dalam kehidupan setaip pribadi menjadi sebuah keniscayaan, yang ditempuh melalui pendidikan baik pendidikan keluarga, sekolah maupun masyarakat. Pendidikan agama dimasud untuk meningkatkan potensi spiritual dan membentuk peserta didik agar menajdi manusia yang beriman dan bertaqwa kepad Allag SWT dan berahlak mulia. Peningkatan potensi spiritual mencakup pengenalan, pemahaman dan penanaman nilai-nilai keagamaan, serta pengamalan nilainilai keagamaan, serta pengalaman nilai-nilai tersebut dalam kehidupan individu ataupun kolektif kemasyarakata. Peningkatan potensi spiritual tersebut pada akhirnya bertujuan pada optimalisasi berbagai potensi yang dimiliki manusia yang aktualisasinya mencerminkan harkat dan martabat sebagai mahkluk ciptaan Allah.

Menurut Darwyan Syah dan Supardi (2014) mengemukakan "Pendidikan Agama Islam adalah upaya sadar dan terencana dalam menyiapkan peserta didik untuk mengenal, memahami, menghayati hingga mengimani, bertaqwa dan berakhlak mulia dalam menjalankan ajaran Agama Islam dari sumber utamanya kitab suci Al-Quran dan Hadist melalui kegiatan bimbingan, pengajaran, dan latihan serta penggunaan pengalaman. Pendidikan Agama Islam merupakan usaha bimbingan dan asuhan terhadap anak didik, agar nantinya setelah selesai menempuh pendidikan peserta didik dapat memahami, menghayati, dan mengamalkan ajaran-ajaran Agama Islam sebagai suatu pandangan hidup demi keselamatan dan kesejahtraan hidup dunia maupun akhirat kelak.

$$
\text { Pada mata pelajaran }
$$

pendidikan agama islam pada khususnya harus dapat diterima oleh masyarakat. Sebab, mengingat dewasa ini pendidikan agama islam banyak dikritik oleh masyarakat dengan alasan tidak bisa mendidik peserta didik secara optimal dan tidak dapat diterima oleh akal sehatnya sehingga terjadi banyaknya kenakalan remaja saat ini, dikarenakan kurangnya ilmu pengetahuan yang di dadapat disekolah. Kurangnya pengawasan dari orang tua dan faktor lingkungan yang kurang mendukung sehinga menyebabkan anak-anak kurang berhasil dalam belajar dan mengaplikasikan ilmunya dalam kehidupan sehari-harinya. Faktor seperti itulah pendidikan di Indonesia ini sedang memperihatinkan, khsusunya Pendidikan Agama Islam yang mana menjadi pusat perbincnagan karena minimmnya pendidikan secara nyata dan kurang memotivasi pesera untuk belajar. Untuk itu perlulah pendidikan ini khususnya pendidikan agama islam harus bisa milih strategi untuk bisa mengebangkan ilmu pengetahuan dan teknologi agar nantinya pada saat guru menyampaikan guru bisa diterima dan dicapai peserta didik. Dengan begitu ilmu pengetahuan tentnag agama islam dapat diterima dan 
dapat diaplikasikan dalam kehidupan sehari-hari.

$$
\text { Hasil supervisi yang }
$$

dilakukan kepala sekolah pada mata pelajaran Agama Islam di SMP Negeri 2 Binjai Kab. Langkat TP. 2017/2018 Kelas VII-1 Semester genap diperoleh beberapa kekurangan dalam proses belajar mengajar diantaranya kurangnya aktivitas belajar siswa dalam hal bertanya dan memberi tanggapan selama proses belajar mengajar, siswa tidak antusias dalam mengikuti proses belajar megajar dalam hal mengobservasi, mengumpulkan data dan mengolah data. Dalam proses belajar mengajar guru juga melakukan tes diakhir pembelajaran, ditemukan hasil belajar siswa masih rendah dimana 26 orang siswa ada sebanyak 10 orang siswa yang tidak tuntas Kriteria Minimum Belajar (KBM) Pendidikan Agama Islam yaitu 75. Temuan ini menjadi bahan diskusi antara guru dan kepala sekolah yang melakukan supervisi, beberapa temuan yang menjadi akar masalah dalam pembelajaran tersebut yaitu, guru mengajar masih mendominasi artinya guru masih kurang mengaktifkan siswa dalam pembelajaran, metode pembelajaran yang diterapkan sangat didominasi oleh metode ceramah, media pembelajaran dan praktek dalam pendidikan agama islam sangat minim.

Salah satu metode yang disarankan untuk diterapkan metode demonstrasi menurut Suaedy (2011) metode demonstrasi adalah suatu cara penyampaian materi dengan memperagakan suatu proses atau kegiatan. Pengertian metode demonstrasi menurut Muhibbin Syah (2000) adalah metode mengajar dengan cara memperagakan barang, kejadian, aturan dan urutan melakukan kegiatan, baik secara langsung maupun melalui penggunaan media pengajaran yang relevan dengan pokok bahasan atau materi yang sedang disajikan.

Menurut Aris Shoimin (2013) suatu model pembelajaran yang dapat digunakan dalam pengajaran sholat adalah metode demsntrasi, dimana metode mengajar dengan cara memperagakan suatu kegiatan, barang, kejadian, dan urutan melakukan aturan, baiks ecara langsung maupun melalui penggunaan media pengajaran yang relevan dengan pokok bahasan dan materi yang sedang disajikan. Demonstrasi dapat digunakan dalam berbagai macam mata pelajaran, dari ilmu-ilmu eksak, ilmu social, maupun Bahasa dari jenjang pendidikan dasar, SMP, SMA hingga perguruan tinggi. Metode demonstrasi adalah salah satu metode pembelajaran kooperatif yang mudah diterapkan, melibatkan aktivitas seluruh siswa tanpa harus ada perbedaan status, dan melibatkan peran siswa sebagai tutor sebaya.

\section{METODE PENELITIAN}

\begin{tabular}{ll}
\multicolumn{2}{c}{ Model penelitian yang } \\
peneliti gunakan dengan jenis \\
Penelitian Tindakan Kelas yang \\
bertujuan untuk memecahkan suatu
\end{tabular}


permasalahan yang di lakukan dengan mendiagnosa siswa untuk lebih aktif pada saat melakukan proses pembelajaran dan untuk meningkatkan hasil belajar siswa melalui model demonstration pada mata pelajaran Pendidikan Agama Islam.

\section{HASIL PENELITIAN DAN PEMBAHASAN}

Siklus I

Proses belajar mengajar menggunakan model pembelajaran demonstrasi, adapun Kriteria Belajar Minimal Mata Pelajaran IPA $(\mathrm{KBM}=75)$ diperoleh hasil belajar siswa tertera pada gambar. 1 dibawah ini.

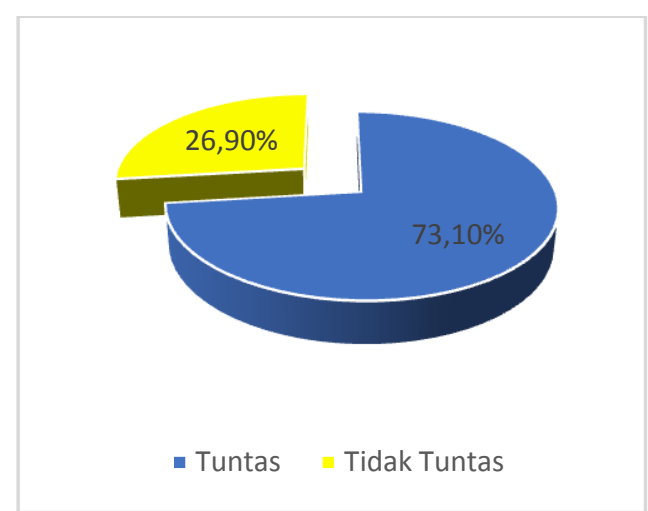

Gambar.1 Hasil Belajar PAI Siklus I

Dari gambar 1 diatas diperoleh hasil belajar PAI kelas VII1 SMP Negeri 2 Binjai Kab. Langkat Tahun Pelajaran 2017/2018, dapat ditarik kesimpulan bahwa pembelajaran dengan menggunakan model pembelajaran Demonstrasi dalam meningkatkan hasil belajar dari 26 orang siswa diperoleh 19 orang yang tuntas dengan $73,1 \%$ dan 7 orang yang tidak tuntas dengan 26,9\%. Pada siklus 1 ini hasil belajar siswa sudah meningkat cukup baik, namun masih belum tercapai ketuntasan klasikal. Beberapa temuan yang menjadi bahan refleksi pada siklus I yaitu siswa terkendalam dalam mengumpulkan data dan mengolah data. Penerapan model pembelajaran ini juga mengukur keterampilan siswa dalam sholat jamak qasar, hasil observasi keterampilan siswa dalam sholat jamak dan qasar dapat dilihat pada penjelasan hasil observasi keterampilan sholat jamak dan qasar penerapan model pembelajaran demonstrasi, diperoleh dari 26 siswa yang ada di kelas VII-1 SMP Negeri 2 Binjai Kab. Langkat, sebanyak 7 orang siswa keterampilan sholat jamak dan qasar dikategorikan (MB), Mulai Berkembang (apabila peserta didik sudah memperlihatkan berbagai tanda perilaku yang dinyatakan dalam indikator dan mulai konsisten), dan 19 orang siswa keterampilan sholat jamak dan qasar Kategori (MT) Mulai Terlihat (apabila peserta didik sudah mulai memperlihatkan adanya tanda-tanda awal perilaku yang dinyatakan dalam indikator tetapi belum konsisten). Dan ketiga aspek ini masih perlu diperhatikan guru untuk meningkatkannya keterampilan siswa.

\section{Siklus II}

Perencanaan siklus II berdasarkan kendala dan kelemahan yang ditemukan pada siklus I dari hasil belajar dan observasi keterampilan siswa pada penerapan 
model pembelajaran demonstrasi, agar kendala dan kelemahan pada siklus I tidak terjadi lagi maka guru berupaya semaksimal mungkin untuk mengontrol kegiatan proses belajar mengajar dan memberikan motivasi kepada siswa saat praktek dan menugaskan siswa untuk latihan dirumah. Hasil belajar siswa tertera pada gambar 2 .

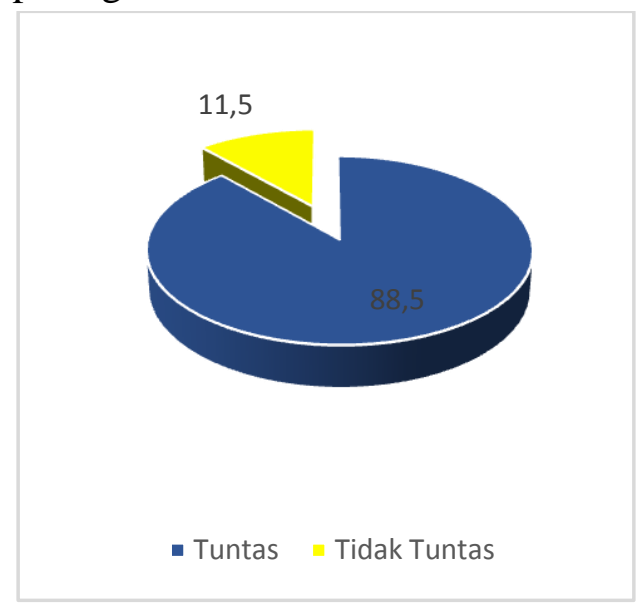

Gambar 2. Hasil Belajar PAI Siklus II

Dari gambar. 2 diatas diperoleh hasil belajar PAI kelas VII-1 SMP Negeri 2 Binjai Kab. Langkat Tahun Pelajaran 2017/2018, dapat ditarik kesimpulan bahwa pembelajaran dengan menggunakan model pembelajaran Demonstrasi dalam meningkatkan hasil belajar siswa dari 26 orang siswa diperoleh 23 orang yang tuntas dengan $88,5 \%$ dan 3 orang yang tidak tuntas dengan $11,5 \%$. Pada siklus II terjadi peningkatan hasil belajar PAI secara signifikan dan dapat dikatakan tuntas secara klasikal.

\section{Pembahasan}

Penerapan model pembelajaran ini juga mengukur keterampilan literasi sains siswa, hasil observasi keterampilan keterampilan sholat jamak dan qasar dapat dilihat hasil observasi keterampilan sholat jamak dan qasar penerapan model pembelajaran demonstrasi, diperoleh dari 26 siswa yang ada di kelas VII-1 SMP Negeri 2 Binjai Kab. Langkat, sebanyak 7 orang siswa keterampilan sholat jamak dan qasar dikategorikan (MK) Membudaya/kebiasaan (apabila peserta didik terus menerus memperlihatkan perilaku yang dinyatakan dalam indikator secara konsisten), Sebanyak 19 orang siswa masuk kategori (MB) Mulai Berkembang (apabila peserta didik sudah memperlihatkan berbagai tanda perilaku yang dinyatakan dalam indikator dan mulai konsisten.

\section{SIMPULAN}

Berdasarkan temuan hasil penelitian dengan judul "Upaya Meningkatkan Hasil Belajar Pendidikan Agama Islam Pada Pokok Bahasan Sholat Jamak dan Qashar Melalui Penerapan Metode Pembelajaran Demonstrasi Di Kelas VII-1 SMP Negeri 2 Binjai Kab. Langkat T.P. 2017/2018", dapat ditarik kesimpulan sebagai berikut :

a. Pada Siklus I penerapan model pembelajaran Demonstrasi memperoleh hasil belajar siswa dari 26 orang siswa diperoleh 19 orang yang tuntas dengan $73,1 \%$ dan 7 orang yang tidak tuntas dengan 26,9\%. Hasil penilaian keterampilan sholat jamak dan qasar dari 26 siswa sebanyak 7 
orang siswa keterampilan sholat jamak dan qasar dikategorikan (MB), Mulai Berkembang (apabila peserta didik sudah memperlihatkan berbagai tanda perilaku yang dinyatakan dalam indikator dan mulai konsisten), dan 19 orang siswa keterampilan sholat jamak dan qasar Kategori (MT) Mulai Terlihat (apabila peserta didik sudah mulai memperlihatkan adanya tandatanda awal perilaku yang dinyatakan dalam indikator tetapi belum konsisten).

b. Pada siklus II hasil belajar siswa dari 26 orang siswa diperoleh 23 orang yang tuntas dengan $88,5 \%$ dan 3 orang yang tidak tuntas dengan $11,5 \%$ observasi keterampilan sholat jamak dan qasar penerapan model pembelajaran demonstrasi, diperoleh dari 26 siswa yang ada di kelas VII-1 SMP Negeri 2 Binjai Kab. Langkat, sebanyak 7 orang siswa keterampilan sholat jamak dan qasar dikategorikan (MK) Membudaya/kebiasaan (apabila peserta didik terus menerus memperlihatkan perilaku yang dinyatakan dalam indikator secara konsisten), Ssebanyak 19 orang siswa masuk kategori (MB) Mulai Berkembang (apabila peserta didik sudah memperlihatkan berbagai tanda perilaku yang dinyatakan dalam indikator dan mulai konsisten. Dari temuan penelitian ini dapat ditarik kesimpulan penerapan metode pembelajaran demonstrasi dapat meningkatkan hasil belajar dan keterampilan sholat jamak dan qasar siswa kelas VII-1 SMP Negeri 2 Binjai Kab. Langkat TP. 2017/2018.

\section{DAFTAR RUJUKAN}

Abdul, Latief. 2006. Perencanaan Sistem Pengajaran Pendidikan Agama Islam. Bandung: Pustaka Bani Quraisy.

Aris, Shoimin. 2013. Model Pembelajaran Inovatif Dalam Kurikulum 2013. Yogyakarta: Ar-Ruzz Media

Darwin, Syah. 2007. Perencanaan Sistem Pengajaran Pendidikan Agama Islam. Ciputat: Haja Mandiri

Darwyan, Syah dan Supardi. 2014. Evaluasi Pembelajaran Pendidikan Agama Islam. Ciputat: Haja Mandiri

Deni, Kurniawan. 2014. Pembelajaran Terpadu TEMATIK (Teori, Praktik, dan Penilaian), Cet. Ke-1. Bandung: CV. Alfabeta

Hanafiah, Cucu Suhana. 2009. Konsep Strategi Pembelajaran, (Bandung: PT. Refika Aditama Ismail. 2008. Strategi Pembelajaran Agama Islam Berbasis PAIKEM. Semarang: RaSial Media Grup.

Thobroni, M., Arif Mustofa. 2013. Belajar Dan Pembelajaran. Yogjakarta: Ar-Ruzz Media 